
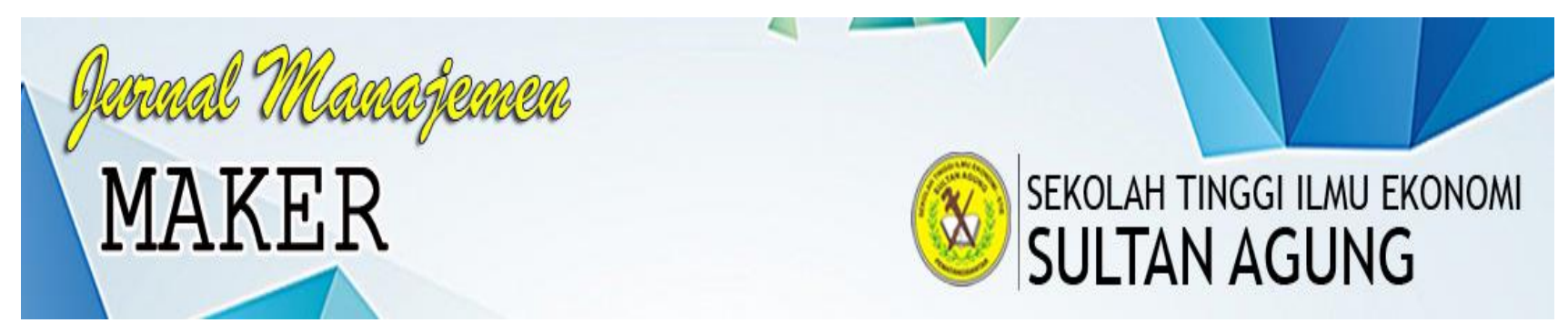

\title{
PENGARUH KEPRIBADIAN DAN MOTIVASI TERHADAP KINERJA PEGAWAI PADA KANTOR KEMENTERIAN AGAMA KOTA PEMATANGSIANTAR
}

\author{
Oleh: \\ Kiki Fatmala \\ Sarjana Manajemen \\ Darwin Lie, Efendi, Lora Ekana Nainggolan
}

\begin{abstract}
Abstrak
Hasil penelitian ini dapat disimpulkan sebagai berikut: 1. Kepribadian, motivasi, dan kinerja pegawai sudah baik. 2. Hasil regresi linier berganda terdapat pengaruh positif antara kepribadian dan motivasi terhadap kinerja pegawai. 3. Hasil analisis koefisien korelasi terdapat hubungan yang kuat dan positif antara kepribadian, motivasi dengan kinerja pegawai. Kemudian diperoleh nilai koefisien determinasi artinya tinggi rendahnya kinerja pegawai dapat dijelaskan oleh kepribadian dan motivasi 4. Hasil uji hipotesis menyatakan $\mathrm{H}_{0}$ ditolak, artinya kepribadian dan motivasi berpengaruh positif dan signifikan terhadap kinerja pegawai pada Kantor Kementerian Agama Kota Pematangsiantar baik secara simultan maupun parsial.
\end{abstract}

Kata Kunci: Kepribadian, Motivasi, dan Kinerja Pegawai

\section{Abstract}

The suggestation of this research results are: 1. To improve personality employees in carrying out tasks should pay attention to the time and result of what is done. 2. To increase motivation it is better if agencies provide bonuses or incentives and hold annual or monthly holidays so that they can increase the motivation and work spirit of employee. 3. To improve the employee performance of employees should complete their tasks according to the targets set by the agency.

\section{Keywords: Personality, Motivation, and Employee Performance}

\section{A. PENDAHULUAN}

\section{Latar Belakang Masalah}

Kementerian agama adalah suatu organisasi yang bertugas untuk menyelenggarakan fungsi pemerintahan dalam pembimbingan dan pengelolaan fungsi administratif dari kegiatan keagamaan di indonesia. Pada kantor Kementerian Agama terutama Kota Pematangsiantar bergerak di berbagai bidang diantaranya bidang kepegawaian, pelaksanaan haji dan umrah, bimas islam, urusan agama kristen, bimas katolik dan sebagainya. Oleh karena itu Kantor Kementerian Agama Kota Pematangsiantar perlu memperhatikan kinerja pegawai sebagai salah satu upaya yang menentukan keberhasilan instansi. Dimensi sasaran kerja pegawai pada indikator waktu, dimana pegawai dalam melakukan tugasnya sering tidak tepat waktu dan hasil kerja menjadi tidak efektif atau memakan banyak waktu sehingga pekerjaan lain tertunda dan menumpuk. Pada dimensi perilaku kerja dalam indikator disiplin, hal ini terlihat masih ada pegawai yang kurang disiplin terhadap instansi dengan bolos dalam bekerja dengan memanfaatkan absensi fingerprint, pegawai yang masuk kerja namun tidak melaksanakan tugas pokoknya sehingga menghambat setiap pekerjaan yang ada dalam instansi. Faktor yang diindikasikan mempengaruhi kinerja pegawai diantaranya adalah kepribadian. Fenomena kepribadian yang belum optimal terjadi pada dimensi keterbukaan dapat dilihat dari suatu tingkat dimana pegawai kurang optimal dalam berkomunikasi, bergaul, dan tidak mudah berbagi pengalaman atau pengetahuan terkait 
dengan pekerjaan sehingga pekerjaan dalam setiap individu terhambat.

Pada dimensi kehati-hatian, dapat dilihat dimana fenomena yang ada menunjukkan hasil kerja pegawai yang masih banyak mendapat keluhan dan kurang rapi, serta masih ada beberapa pegawai yang kurang memiliki tanggung jawab pada setiap tugas yang diberikan oleh instansi. Faktor yang juga diindikasikan mampu mempengaruhi kinerja pegawai pada Kantor Kementerian Agama Kota Pematangsiantar adalah motivasi. Fenomena motivasi terjadi pada dimensi kebutuhan akan prestasi dimana ada beberapa pegawai yang kurang semangat untuk mencapai prestasi kerja yang sudah ditentukan oleh instansi, hal ini terlihat kinerja bukan semakin baik tetapi justru menurun. Pada dimensi kebutuhan akan kekuasaan juga belum optimal dimana fenomena yang ada menunjukkan bahwa masih ada beberapa pegawai yang masih belum optimal usahanya dalam menghadapi tantangan pekerjaannya untuk meraih suatu jabatan tertentu dalam instansi.

\section{Rumusan Masalah}

a. Bagaimana gambaran kepribadian, motivasi, dan kinerja pegawai pada Kantor Kementerian Agama Kota Pematangsiantar.

b. Bagaimana pengaruh kepribadian dan motivasi terhadap kinerja pegawai pada Kantor Kementerian Agama Kota Pematangsiantar baik secara simultan maupun parsial.

\section{Tujuan Penelitian}

a. Untuk mengetahui gambaran kepribadian, motivasi, dan kinerja pegawai pada Kantor Kementerian Agama Kota Pematangsiantar.

b. Untuk mengetahui pengaruh kepribadian dan motivasi terhadap kinerja pegawai pada Kantor Kementerian Agama Kota Pematangsiantar baik secara simultan maupun parsial.

\section{Metode Penelitian}

Lokasi atau tempat penelitian ini dilakukan pada tanggal 21 mei 2018 pada Kantor Kementerian Agama Kota Pematangsiantar yang terletak di Jl. Brigjend Rajamin Purba, SH No 122
Telepon (0622) 21131, Fax. (0622) 435919 Pematangsiantar-21139. Pada penelitian ini populasi yang digunakan pada Kantor Kementerian Agama Kota Pematangsiantar adalah pegawai tetap yang berjumlah 59 orang $(\mathrm{N}=59)$. Dimana sampel penarikan adalah seluruh pegawai sebanyak 59 orang yang akan menjawab kuesioner yang penulis sebarkan, mengingat jumlahnya kurang dari 100 (seratus) orang dan ketersediaan waktu penulis serta untuk keakuratan hasil penelitian.

Desain penelitian adalah Penelitian Kepustakaan (Library Research) danPenelitian Lapangan (Field Research).Teknik pengumpulan data berupa Kuesioner, Wawancara dan Dokumentasi.Jenis data yang adalah jenis data kualitatif dan data kuantitatif. Hasil data yang diperoleh dari lapangan akan dianalisis secara deskriptif baik bersifat kualitatif dan kuantitatif.

\section{B. LANDASAN TEORI}

\section{Manajemen dan Manajemen Sumber Daya Manusia}

Menurut Griffin (2004:8), manajemen adalah "suatu rangkaian aktivitas (termasuk perencanaan dan pengambilan keputusan, pengorganisasian, kepemimpinan, dan pengendalian) yang diarahkan pada sumber daya organisasi (manusia, finansial, fisik, dan informasi) untuk mencapai tujuan organisasi dengan cara yang efektif dan efisien". Sedangkan menurut Gaol (2014:38), manajemen yaitu "proses kerjasama antara dua orang atau lebih dalam rangka mencapai tujuan-tujuan yang sudah ditetapkan sebelumnya".

Lalu menurut Rivai (2009:4), istilah manajemen mempunyai arti sebagai "kumpulan pengetahuan tentang bagaimana seharusnya mengelola sumber daya manusia”. Berdasarkan pendapat ahli tersebut, maka dapat disimpulkan bahwa manajemen adalah proses yang terdiri dari perencanaan, pengorganisasian serta untuk mencapai tujuan suatu melalui pemanfaatan sumber daya manusia dan sumber daya lainnya.

Menurut Edison, Yohny dan Imas (2016:10), manajemen sumber daya manusia merupakan "manajemen yang 
memfokuskan diri memaksimalkan kemampuan karyawan atau anggotanya melalui berbagai langkah strategis dalam rangka meningkatkan kinerja pegawai/ karyawan menuju pengoptimalan tujuan organisasi”. Menurut Sutrisno (2011:7), "manajemen sumber daya manusia sebagai suatu perencanaan, pengorganisasian, pengarahan dan pengawasan atas pengadaan, pengembangan, kompensasi, pengintegrasian, pemeliharaan dan pemutusan hubungan kerja dengan maksud untuk mencapai tujuan organisasi perusahaan secara terpadu".

Sedangkan menurut Kasmir (2016:6), manajemen sumber daya manusia adalah "proses pengelolaan manusia melalui perencanaan, rekrutmen, seleksi, pelatihan, pengembangan, pemberian kompensasi, karier, keselamatan dan kesehatan kerja guna mencapai tujuan perusahaan dan peningkatan kesejahteraan". Manajemen sumber daya manusia adalah proses pengelolaan manusia melalui seleksi dan rekrutmen yang penting dilakukan oleh suatu organisasi untuk mencapai kinerja pegawai yang baik. Berdasarkan pendapat ahli tersebut, dapat disimpulkan bahwa manajemen sumber daya manusia adalah segala ilmu yang berfokus pada tenaga kerja mulai dari rekruitmen, seleksi, perencanaan pengorganisasian, pelaksanaan dan pengendalian tenaga kerja agar dapat menggunakan bakatnya secara efektif dan efesien sehingga tujuan organisasi dapat terwujud secara maksimal.

\section{Kepribadian}

Menurut Sule dan Kurniawan (2005:219), menyatakan bahwa kepribadian merupakan "karakteristik psikologis dan perilaku dari individu yang sifatnya relatif permanen yang membedakan satu individu tenaga kerja dengan individu lainnya". Menurut Kreitner dan Kinicki (2014:133), kepribadian didefenisikan sebagai "kombinasi karakteristik fisik dan mental yang stabil yang memberikn identitas individualnya. Karakteristik atau ciri, sifat ini termasuk bagaimana orang melihat, berpikir, bertindak, dan merasakan, yang merupakan produk interaksi genetik dan pengaruh lingkungan".
Sedangkan menurut Luthans (2005:228), "kepribadian berarti bagaimana orang mempengaruhi orang lain dan bagaimana mereka memahami dan memandang dirinya, juga bagaimana pola ukur karakter dalam dan karakter luar mereka mengukur trait dan interaksi antara manusia dan situasi”. Berdasarkan pendapat para ahli tersebut, dapat disimpulkan bahwa kepribadian adalah determinan paling penting bagi individu, karena kepribadian menentukan bagaimana seseorang berpikir, berperilaku dan berperasaan dalam berbagai situasi dan keadaan yang berbeda-beda.

\section{Motivasi}

Menurut Griffin (2004:38), motivasi adalah "sekelompok faktor yang menyebabkan individu berperilaku dalam cara-cara tertentu". Menurut Sutrisno (2011:109), motivasi yaitu "suatu faktor yang yang mendorong seseorang untuk melakukan suatu aktivitas tertentu, oleh karena itu motivasi sering kali diartikan pula sebagai faktor pendorong perilaku seseorang".

Sedangkan menurut Luthans (2005:270), motivasi adalah "proses yang dimulai dengan fisiologis atau psikologis yang menggerakkan perilaku atau dorongan yang ditujukan untuk tujuan atau insentif'. Berdasarkan pendapat parah ahli tersebut, maka dapat disimpulkan bahwa motivasi adalah suatu dorongan yang ada dalam diri seseorang untuk melakukan suatu kegiatan guna untuk mencapai suatu tujuan tertentu.

\section{Kinerja Pegawai}

Menurut Bangun (2012:231), kinerja yaitu "hasil pekerjaan yang dicapai seseorang berdasarkan persyaratanpersyaratan pekerjaan suatu pekerjaan mempunyai persyaratan tertentu untuk dapat di lakukan dalam mencapai tujuan yang di sebut juga sebagai standar pekerjaan (job standard)". Adapun menurut Sutrisno (2011:170), mengemukakan kinerja adalah "kesuksesan seseorang dalam melaksanakan tugas". Sedangkan menurut Kasmir (2016:182), kinerja merupakan "hasil kerja dan perilaku kerja yang telah dicapai dalam menyelesaikan tugas-tugas dan tanggung jawab yang diberikan dalam suatu periode terakhir". Berdasarkan 
pendapat para ahli tersebut, dapat disimpulkan bahwa kinerja adalah hasil kerja yang dicapai oleh pegawai dalam melakukan tugasnya dengan tanggung jawab baik secara kualitas maupun kuantitas.

Kinerja Pegawai pada Kantor Kementerian Agama Kota Pematangsiantar dinilai berdasarkan Peraturan Pemerintah Nomor 46 Tahun 2011 tentang Penilaian Prestasi Kerja Pegawai yang meliputi:

Sasaran Kinerja Pegawai (SKP) Yaitu rencana kerja dan target yang akan dicapai oleh seorang PNS dan dilaksanakan dalam waktu sekali setahun oleh pejabat penilai. Sasaran kinerja pegawai meliputi unsur sebagai berikut: Kuantitas Kerja, merupakan ukuran jumlah atau banyaknya hasil kerja yang diperoleh oleh seorang pegawai, Kualitas Kerja, merupakan mutu setiap hasil kerja yang dicapai oleh seorang pegawai, Waktu, yaitu ukuran lamanya proses setiap hasil kerja yang dicapai oleh seorang pegawai, Biaya, merupakan besar jumlah anggaran yang digunakan setiap hasil kerja oleh seorang pegawai.

Perilaku Kerja Merupakan setiap tingkah laku, sikap atau tindakan yang dilakukan oleh seorang pegawai yang seharusnya dilakukan maupun tidak dilakukan sesuai dengan ketentuan yang berlaku. Adapun unsur perilaku kerja meliputi: Orientasi Pelayanan, merupakan sikap dan perilaku kerja pegawai dalam memberikan pelayanan kepada yang dilayani antara lain meliputi masyarakat, atasan, rekan kerja, unit kerja terkait dan instansi lain, Integritas merupakan menjalankan norma-norma sosial dan etika organisasi dengan memegang teguh aturan pelaksanaan dan prinsip-prinsip etika, Komitmen merupakan kemauan dan kemampuan seorang pegawai untuk dapat menyeimbangkan antara sikap dan tindakan untuk mewujudkan tujuan organisasi dengan mengutamakan kepentingan dinas dari pada kepentingan diri sendiri, seseorang atau golongan.

Disiplin merupakan kesanggupan seorang pegawai untuk menaati kewajiban dan menghindari larangan yang telah ditentukan, Kerjasama merupakan kemauan dan kemampuan seorang pegawai untuk bekerjasama dengan rekan sekerja, atasan, bawahan baik dalam unit kerjanya maupun instansi lain dalam menyelesaikan suatu tugas dan tanggung jawab yang diembannya, Kepemimpinan merupakan kemampuan dan kemauan seseorang untuk memotivasi dan mempengaruhi bawahan atau orang lain yang berkaitan dengan tugasnya demi tercapainya tujuan organisasi.

\section{PEMBAHASAN}

\section{Analisis}

\section{a. Deskriptif Kualitatif}

Analisis deskriptif dimaksudkan untuk mendapatkan gambaran atau deskripsi mengenai Pengaruh gaya kepemimpinan kepala sekolah dan lingkungan kerja terhadap kinerja guru Yayasan Perguruan Maria goretti Pematangsiantar. Adapun penetapan kriteria nilai rata-rata jawaban dari responden tersebut dimasukkan ke dalam kelas-kelas interval dengan memakai rumus sebagai berikut:

$$
\begin{aligned}
& \text { Interval kelas }=\frac{\text { Nilai Tertinggi }- \text { Nilai Terendah }}{\text { (jumlah kelas interval) }} \\
& =\frac{5-1}{5} \\
& =\frac{4}{5} \\
& =0,8
\end{aligned}
$$

Dari rumus di atas, diperoleh nilai interval kelas $=0,8$, sehingga berlaku ketentuan kategori dengan hasil sebagai berikut:

Tabel 1

Nilai Interval dan Kategori Jawaban Responden

\begin{tabular}{|c|c|}
\hline $\begin{array}{c}\text { Nilai } \\
\text { Interval }\end{array}$ & Kategori \\
\hline $1,00-1,80$ & Sangat Tidak Baik (STB) \\
\hline $1,81-2,60$ & Tidak Baik (TB) \\
\hline $2,61-3,40$ & Cukup Baik (CB) \\
\hline $3,41-4,20$ & Baik (B) \\
\hline $4,21-5,00$ & Sangat Baik (SB) \\
\hline
\end{tabular}

Sumber: data diolah

\section{1) Gambaran Kepribadian Pada Kantor Kementerian Agama Kota Pematangsiantar}

Pada dimensi keterbukaan dalam indikator mudah bergaul dengan rekan kerja berada pada rata-rata 3,28 dengan kriteria jawaban cukup baik, hal ini terlihat ada 
beberapa pegawai yang sulit untuk berkomunikasi, berdialog dan sulit berbagi pengalaman atau pengetahuan yang terkait dengan pekerjaan yang dilakukan, hal ini karena pegawai merasa enggan untuk berkomunikasi dengan rekan kerja yang sudah senior atau bekerja lebih lama. Indikator ketegasan dalam mengambil keputusan berada pada rata-rata 3,84 dengan kriteria jawaban baik, hal ini karena pegawai dapat meningkatkan ketegasannya dalam mengambil keputusan dan tepat dengan pendiriannya. Indikator kenyamanandalam bekerja berada pada ratarata 3,89 dengan kriteria jawaban baik, hal ini karena pegawai merasakan kenyamanan di lingkungan kerja nya sehingga dapat bekerja dengan baik.

Pada dimensi keramah-tamahan pada indikator untuk saling memaafkan berada pada rata-rata 4,11 dengan kriteria jawaban baik, hal ini karena pegawai dapat saling memaafkan apabila terdapat kesalahakesalahan pada setiap pekerjaannya. Indikator memberikan pengertian sesama pegawai berada pada rata-rata 3,84 dengan kriteria jawaban baik, hal ini karena pegawai dapat saling memberi pengertian antar rekan kerja sehingga terjalin hubungan dengan baik. Indikator memberi kepercayaan kepada tim kerja berada pada rata-rata 3,74 dengan kriteria jawaban baik, hal ini karena pegawai dapat saling memberi kepercayaan dengan tim kerja secara baik.

Dimensi kehati-hatian pada Indikator ketelitian dalam menyelesaikan pekerjaan berada pada rata-rata 4,01 dengan kriteria jawaban baik, hal ini terlihat sebagian pegawai memiliki sikap ketelitian dalam menyelesaikan pekerjaan dengan baik agar pekerjaan yang diselesaikannya menghasilkan nilai yang baik sesuai dengan standart yang telah ditentukan oleh instansi. Indikator berperilaku baik berada pada ratarata 4,05 dengan kriteria jawaban baik, hal ini karena pegawai dapat berperilaku baik dalam melayani masyarakat sehingga masyarakat merasa nyaman dan hasil kerja pun menjadi baik. indikator bertanggung jawab dalam melaksanakan pekerjaan berada pada rata-rata 3,25 dengan kriteria jawaban cukup baik, hal ini terihat masih ada hasil kerja pegawai yang masih mendapat keluhan dan kurang rapi, hal ini karena pegawai tidak serius dan tidak memahami apa yang seharusnya mereka kerjakan sehingga hasil kerja menjadi tidak efektif, serta masih ada beberapa pegawai yang belum dapat bertanggung jawab pada setiap tugasnya sehingga hasil kerja yang diperoleh tidak sesuai dengan apa yang diharapkan oleh instansi. Pada dimensi kestabilan emosi pada indikator penyesuaian diri terhadap lingkungan kerja berada pada rata-rata 3,86 dengan kriteria jawaban baik, hal ini karena pegawai dapat menyesuaikan dirinya dilingkungan tempat kerjanya dengan baik sehingga dalam hal ini pegawai merasa nyaman dalam melaksanakan pekerjaannya.

Indikator bersikap tenang dalam bekerja berada pada rata-rata 4,01 dengan kriteria jawaban baik, hal ini karena pegawai dapat mengerjakan tugasnya dengan tenang dan santai sehingga pekerjaan dapat selesai dengan baik. Indikator tidak tegang berada pada rata-rata 3,84 dengan kriteria jawaban baik, hal ini karena pegawai tidak tegang dalam mengatasi permasalahan yang ada dalam setiap pekerjaannya dan dapat menahan emosi nya sehingga hasil kerja yang dicapai optimal.

Selanjutnya dimensi keterbukaan pada pengalaman pada indikator menemukan ideide baru berada pada rata-rata 3,89 dengan kriteria jawaban baik, hal ini karena pegawai dapat mengembangkan ide-ide baru yang diperlukan dalam setiap permasalahan yang ada dalam pekerjaan sehingga hasil kerja menjadi baik. Indikator keaktifan dalam mencari informasi terkait pekerjaan berada pada rata-rata 4,11 dengan kriteria jawaban baik, hal ini karena pegawai aktif dalam menemukan informasi terkait dengan pekerjaannya sehingga hasil kerja mencapai hasil yang baik. Pada indikator imajinasi dalam bekerja berada pada rata-rata 3,84 dengan kriteria jawaban baik, hal ini karena pegawai dapat menggunakan imajinasi atau pemikiran yang baik tentang pekrjaannya sehingga menghasilkan pekerjaan yang baik. 
Secara keseluruhan mengenai dimensi keterbukaan, keramah-tamahan, kehatihatian, kestabilan emosi, dan keterbukaan pada pengalaman mendapat nilai rata-rata sebesar 3,84 dengan kriteria jawaban baik. Kemudian nilai rata-rata tertinggi 4,11 dengan kriteria jawaban baik untuk dimensi keterbukaan pada indikator sikap untuk saling memaafkan. Sedangkan nilai rata-rata terendah sebesar 3,25 dengan kriteria jawaban cukup baik untuk dimensi kehatihatian pada indikator tanggung jawab dalam menyelesaikan pekerjaannya.

\section{2) Gambaran Motivasi Pada Kantor Kementerian Agama Kota Pematangsiantar}

Dari hasil analisa, dapat dilihat bahwa pada dimensi kebutuhan akan prestasi pada Indikator usaha dalam mencapai pengetahuan untuk meningkatkan prestasi kerja berada pada rata-rata 3,96 dengan kriteria jawaban baik, hal ini dikarenakan pegawai diberi kebebasan beraktivitas untuk meningkatkan prestasi kerjanya. Indikator dorongan untuk mencapai prestasi kerja berada pada rata-rata 3,96 dengan kriteria jawaban baik, hal ini karena pegawai mendapatkan dukungan dan dorongan dari pimpinan dalam mencapai prestasi kerja. Indikator semangat dalam mencapai prestasi kerja berada pada rata-rata 3,22 dengan kriteria jawaban cukup baik, hal ini terlihat masih ada beberapa pegawai yang kurang bersemangat dalam mencapai prestasi kerja, dimana dapat dilihat dari jam masuk pegawai yang tidak sesuai dengan peraturan yang telah ditentukan oleh instansi, datang tidak tepat waktu, istirahat melebihi waktu yang telah ditentukan, dan raut wajah yang kurang ceria dalam bekerja, sehingga kinerja pegawai menurun dan tidak sesuai dengan yang diinginkan oleh instansi.

Pada dimensi kebutuhan akan afiliasi, pada indikator hasil kerja dihargai oleh rekan kerja berada pada rata-rata 3,98 dengan kriteria jawaban baik, hal ini karena masukan yang berkualitas dan kreativitas dalam bekerja sehingga kinerja dipandang baik oleh rekan kerja. Indikator rasa bangga dalam mengerjakan setiap tugas yang diberikan pimpinan berada pada rata-rata 4,00 dengan kriteria jawaban baik, hal ini karena pegawai memiliki rasa percaya diri dalam menyelesaikan pekerjaannya. Indikator hubungan dengan rekan kerja berada pada rata-rata 4,20 dengan kriteria jawaban baik, hal ini karena pegawai dapat bersosialisasi dan menjalin silahturahmi dengan baik.

Pada dimensi kebutuhan akan kekuasaan, pada indikator usaha dalam meraih suatu jabatan berada pada rata-rata 3,94 dengan kriteria jawaban baik, hal ini karena pegawai mempunyai niat yang kuat untuk meraih suatu jabatan yang ada dalam instansi. Indikator kemampuan dalam menghadapi tantangan pekerjaan berada pada rata-rata 3,27 dengan kriteria jawaban cukup baik, hal ini terlihat beberapa pegawai masih belum optimal dalam menghadapi tantangan pekerjaannya untuk meraih suatu jabatan tertentu dalam suatu instansi. Indikator keinginan untuk mencapai jabatan barada pada rata-rata 3,88 dengan kriteria jawaban baik, hal ini karena pegawai ingin bekerja dan meraih suatu jabatan yang ada dalam instansi.

Secara keseluruhan kebutuhan akan prestasi, kebutuhan akan afiliasi dan kebutuhan akan kekuasaan mendapat nilai rata-rata 3,82 dengan kriteria jawaban baik. Kemudian nilai rata-rata tertinggi sebesar 4,20 dengan kriteria jawaban baik pada dimensi kebutuhan akan afiliasi pada Indikator hubungan dengan rekan kerja. Sedangkan nilai rata-rata terendah sebesar 3,22 dengan kriteria jawaban cukup baik pada dimensi kebutuhan akan prestasi untuk indikator semangat dalam mencapai prestasi kerja.

\section{3) Gambaran Kinerja Pegawai Pada Kantor Kementerian Agama Kota Pematangsiantar}

Dari hasil analisa, dapat dilihat bahwa dimensi sasaran kerja pegawai pada indikator kuantitas memperoleh nilai ratarata 4,06 dengan kriteria jawaban baik, hal ini dikerenakan dalam setiap bulannya pegawai mampu mencapai target kerjanya dengan baik. Indikator kualitas memperoleh nilai rata-rata 3,89 dengan kriteria jawaban baik, hal ini karena pegawai dapat menciptakan mutu dalam setiap hasil kerja yang di capainya. Pada indikator waktu 
memperoleh nilai rata-rata 3,20 dengan kriteria jawaban cukup baik, hal ini terlihat masih ada pegawai dalam melakukan tugasnya sering tidak tepat waktu, suka menunda-nunda pekerjaan, hal ini disebabkan karena pegawai tidak dapat hadir sesuai dengan peraturan yang ada dalam instansisehingga pekerjaan menumpuk dan hasil kerja menjadi tidak efektif. Pada indikator realisasi anggaran memperoleh nilai rata-rata 3,93 dengan kriteria jawaban baik, hal ini dikarenakan pegawai menerima anggaran sesuai pekerjaanya dengan baik.

Terakhir pada dimensi perilaku kerja pada indikator orientasi pelayanan memperoleh nilai rata-rata 3,91 dengan kriteria jawaban baik, hal ini dikerenakan pegawai dapat melayani masyarakat dengan baik. Indikator integritas memperoleh nilai rata-rata 3,98 dengan kriteria jawaban baik, hal ini dikarenakan pegawai bekerja dengan jujur dan konsisten terhadap instansi dengan baik. Pada indikator komitmen memperoleh nilai rata-rata 3,96 dengan kriteria jawaban baik, hal ini dikarenakan pegawai dapat berkomitmen dalam memajukan instansi dengan baik.

Pada indikator disiplin memperoleh nilai rata-rata 3,33 dengan kriteria jawaban cukup baik hal ini dikarenakan masih ada pegawai yang kurang disiplin terhadap instansi dengan bolos saat bekerja dengan memanfaatkan absensi fingerprint, pegawai yang masuk kerja namun tidak melaksanakan tugas pokoknya sehingga menghambat setiap pekerjaan yang ada dalam instansi. Indikator kerjasama memperoleh nilai rata-rata 4,13 dengan kriteria jawaban baik hal ini karena pegawai mampu bekerjasama dengan baik. Terakhir pada indikator kepemimpinan memperoleh nilai rata-rata 4,15 dengan kriteria jawaban baik hal ini karena pegawai mampu memimpin tim kerja dengan baik.

Secara keseluruhan mengenai dimensi sasaran kerja pegawai dan perilaku kerja mendapat nilai rata-rata sebesar 3,85 dengan kriteria jawaban baik. Kemudian nilai rata-rata tertinggi 4,15 dengan kriteria jawaban baik pada dimensi perilaku kerja pada indikator kepemimpinan. Sedangkan nilai rata-rata terendah sebesar 3,20 dengan kriteria jawaban cukup baik pada dimensi sasaran kerja pegawai pada indikator waktu.

\section{b. Deskriptif Kuantitatif}

\section{1) Analisis Regresi Linear Berganda}

Penelitian ini memiliki tujuan untuk menganalisis pengaruh gaya kepemimpinan dan lingkungan kerja terhadap kinerja guru. Dalam penelitian ini untuk analisis data menggunakan analisis regresi linier berganda. Analisis regresi linier berganda digunakan untuk mengetahui pengaruh variabel bebas $(\mathrm{X})$ dan variabel terikat (Y), dimana $\mathrm{X}$ adalah Kepribadian, motivasi, dan $Y$ adalah kinerja pegawai. Maka dilakukan perhitungan menggunakan program aplikasi SPSS versi 21 dengan hasil hitung regresi sebagai berikut:

Tabel 2

Hasil Regresi Linier Berganda

\begin{tabular}{|l|r|r|r|}
\hline \multicolumn{1}{|c|}{ Model } & \multicolumn{2}{|c|}{$\begin{array}{c}\text { Unstandardized } \\
\text { Coefficients }\end{array}$} & $\begin{array}{c}\text { Standardized } \\
\text { Coefficients }\end{array}$ \\
\hline & \multicolumn{1}{|c|}{ B } & \multicolumn{1}{c|}{$\begin{array}{c}\text { Std. } \\
\text { Error }\end{array}$} & \multicolumn{1}{c|}{ Beta } \\
\hline & $\mathbf{4 , 6 1 3}$ & 5,190 & \\
(Constant) & $\mathbf{5 2 0}$ &, 084 &, 398 \\
Kepribadian & $\mathbf{2 7 9}$ &, 175 &, 359 \\
Motivasi &
\end{tabular}

a. Dependent Variable: Kinerja Pegawai

Sumber : hasil pengolahan data

Berdasarkan hasil pengolahan data pada tabel 2 tersebut, diperoleh model persamaan $\hat{\mathrm{Y}}=4,613+0,520 \mathrm{X}_{1}+0,279 \mathrm{X}_{2}$, artinya terdapat pengaruh positif antara Kepribadian dan Motivasi terhadap Kinerja Pegawai pada Kantor Kementerian Agama Kota Pematangsiantar.

\section{2) Analisis Koefisien Korelasi dan \\ Koefisien Determinan}

Untuk menghitung kekuatan hubungan kepribadian dan motivasi terhadap kinerja pegawai dilakukan analisis korelasi, berupa derajat atau kedalaman hubungan fungsional yang menjelaskan hubungan antara perubah, dinyatakan dengan koefisien korelasi yang disimbolkan dengan $r$ dilihat melalui tabel berikut: 
Tabel 3

Hasil Koefisien Korelasi dan Determinasi

\begin{tabular}{|c|c|c|c|c|}
\hline Model & $\mathbf{R}$ & $\begin{array}{c}\boldsymbol{R} \\
\text { Squar } \\
\boldsymbol{e}\end{array}$ & $\begin{array}{c}\text { Adjusted } \\
\boldsymbol{R} \text { Square }\end{array}$ & $\begin{array}{c}\text { Std. Error } \\
\text { of the } \\
\text { Estimate }\end{array}$ \\
\hline 1 & $\mathbf{6 7 0}^{\mathrm{a}}$ & $\mathbf{4 4 9}$ &, 429 & 4,290 \\
\hline
\end{tabular}

a. Predictors: (Constant), Variabel X1

(kepribadian) X2 (motivasi)

b. Dependent Variable: Variabel Y (Kinerja pegawai)

Sumber : hasil pengolahan data

Dari tabel 3, diperoleh nilai $r=0,670$ yang artinya terdapat hubungan yang kuat dan positif antara kepribadian, motivasi dengan kinerja pegawai pada Kantor Kementerian Agama Kota Pematangsiantar. Selanjutnya diperoleh nilai koefisien determinasi R Square $=0,449$, artinya tinggi rendahnya Kinerja Pegawai pada Kantor Kementerian Agama Kota Pematangsiantar sebesar 44,9\% dapat dijelaskan oleh Kepribadian dan Motivasi sedangkan sisanya sebesar $55,1 \%$ dijelaskani oleh faktor lain seperti komunikasi, budaya organisasi, kompensasi, kepuasan kerja.

\section{3) Uji Hipotesis}

\section{a)Uji Simultan (Uji F)}

Uji $\mathrm{F}$ digunakan untuk mengetahui apakah variabel bebas (kepribadian dan motivasi) berpengaruh terhadap variabel terikat (kinerja pegawai) secara bersamasama atau simultan. Pengujian ini dapat dilihat dari tabel berikut:

\section{Tabel 4}

Perkiraan Nilai Fhitung

\begin{tabular}{|c|c|c|c|c|c|}
\hline Model & $\begin{array}{l}\text { Sum of } \\
\text { Squares }\end{array}$ & Df & $\begin{array}{c}\text { Mean } \\
\text { Squar } \\
\text { e }\end{array}$ & $\mathbf{F}$ & Sig. \\
\hline $\begin{array}{l}\text { Regres } \\
\text { sion }\end{array}$ & 839,660 & 2 & $\begin{array}{r}419,8 \\
30\end{array}$ & $\begin{array}{r}22,81 \\
3\end{array}$ & .000 \\
\hline $\begin{array}{c}1 \text { Residu } \\
\text { al } \\
\text { Total }\end{array}$ & $\begin{array}{l}1030,577 \\
1870,237\end{array}$ & 56 & $\begin{array}{r}18,40 \\
3\end{array}$ & & \\
\hline
\end{tabular}

a. Dependent Variable: Kinerja Pegawai (Y)

b. Predictors: (Constant), kepribadian (X1), motivasi (X2)

Sumber : hasil pengolahan data

Berdasarkan tabel 4, diperoleh nilai $F_{\text {hitung }}$ sebesar 22,813 $>F_{\text {tabel }}$ dengan $(0,05$; 2 vs 56) sebesar 3,16, atau dengan signifikan $0,000<\alpha 0,05$, maka $\mathrm{H}_{0}$ ditolak, artinya kepribadian dan motivasi berpengaruh positif dan signifikan terhadap kinerja pegawai pada Kantor Kementerian Agama Kota Pematangsiantar.

b) Uji Parsial (Uji t)

Untuk menghasilkan suatu kesimpulan yang valid, maka harus dilakukan uji hipotesis (uji t). Hasil perhitungan koefisien korelasi dapat dilihat pada tabel berikut ini:

Tabel 5

Perkiraan Nilai $t_{\text {hitung }}$

\begin{tabular}{|l|c|c|}
\hline \multicolumn{1}{|c|}{ Model } & $\mathbf{t}$ & Sig. \\
\hline (Constant) & $\mathbf{, 8 8 9}$ & $\mathbf{, 3 7 8}$ \\
Kepribadian (X1) & $\mathbf{3 , 2 9 9}$ & $\mathbf{. 0 0 2}$ \\
Motivasi (X2) & $\mathbf{2 , 9 7 8}$ & $\mathbf{. 0 0 4}$ \\
\hline
\end{tabular}

a. Dependent Variable: Kinerja Pegawai

Sumber : hasil pengolahan data

Dari tabel 5, dapat dilihat diperoleh nilai $t_{\text {hitung }}$ pada variabel Kepribadian sebesar 3,299 $>\mathrm{t}_{\text {tabel }}$ dengan $\mathrm{df}=\mathrm{n}-\mathrm{k}-1$ (592-1=56) sebesar 2,003 atau taraf signifikan $0,002<\alpha 0,05$, maka $\mathrm{H}_{0}$ ditolak, artinya kepribadian berpengaruh positif dan signifikan terhadap kinerja pegawai pada Kantor Kementerian Agama Kota Pematangsiantar.

Kemudian nilai $t_{\text {hitung }}$ pada variabel Motivasi sebesar 2,978> dari tabell dengan $\mathrm{df}=\mathrm{n}-\mathrm{k}-1,(59-2-1=56)$ sebesar 2,003 atau taraf signifikan $0,004<\alpha \quad 0,05$, maka $\mathrm{H}_{0}$ ditolak, artinya motivasi berpengaruh positif dan signifikan terhadap kinerja pegawai pada Kantor Kementerian Agama Kota Pematangsiantar.

\section{Evaluasi}

\section{a. Kepribadian Pada Kantor \\ Kementerian Agama Kota \\ Pematangsiantar}

Pada dimensi keterbukaan dengan indikator mudah bergaul diperoleh nilai rata-rata 3,28 dengan kriteria jawaban cukup baik, cara mengatasinya sebaiknya pegawai berkomunikasi secara terbuka antar rekan kerja, diskusi dalam tugas berkelompok dan membantu rekan kerja dalam menyelesaikan pekerjaan yang ada dalam instansi.

Pada dimensi kehati-hatian dengan indikator tanggung jawab dalam melaksanakan pekerjaan diperoleh nilai rata-rata 3,25 dengan kriteria jawaban cukup baik, maka dari itu dalam 
mengerjakan tugas-tugasnya pegawai sebaiknya memperhatikan waktu dan hasil dari apa yang dikerjakan, bekerja dan menyelesaikan pekerjaannya dengan sungguh-sungguh, fokus dalam bekerja, mempunyai semangat yang tinggi dan pantang menyerah dalam mencapai target.

b. Motivasi Pada Kantor Kementerian

\section{Agama Kota Pematangsiantar}

Pada dimensi kebutuhan akan prestasi dengan indikator semangat dalam mencapai prestasi kerja diperoleh nilai rata-rata 3,22 dengan kriteria jawaban cukup baik, cara mengatasinya sebaiknya pimpinan lebih memahami deskripsi pegawai, karakter serta kemampuan pegawai, adanya briefing antar pegawai, diselenggarakan acara outbond pada hari libur dan melengkapi fasilitas yang dibutuhkan.

Pada dimensi kebutuhan akan kekuasaan dalam indikator kemampuan dalam menghadapi tantangan pekerjaan diperoleh nilai rata-rata sebesar 3,27 dengan kriteria jawaban cukup baik, cara mengatasisebaiknya pegawai lebih meningkatkan kemampuan dan memperluas ilmu dengan mengikuti pelatihan yang di adakan dalam instansi.

\section{c. Kinerja Pada Kantor Kementerian Agama Kota Pematangsiantar}

Pada dimensi sasaran kerja pegawai dengan indikator waktu diperoleh nilai ratarata 3,20 dengan kriteria jawaban cukup baik, cara mengatasinya sebaiknya pegawai menyelesaikan tugas yang diberikan sesuai dengan target yang telah ditentukan oleh instansi, lebih memperhatikan jadwal kerja agar dapat menyelesaikan pekerjaan dan menlist kerjaan untuk esok hari agar lebih mudah dikerjakan. Pada dimensi perilaku kerja, pada indikator disiplin dalam melaksanakan pekerjaan dengan tepat waktu diperoleh nilai rata-rata 3.33 dengan kriteria jawaban cukup baik, cara mengatasinya sebaiknya pimpinan memberikan sanksi kepada pegawai seperti tidak memberikan bonus, memberikan denda untuk keterlambatan masuk kerja agar ada efek jera.

\section{KESIMPULAN DAN SARAN}

\section{Kesimpulan}

a. Hasil analisis deskriptif kualitatif tentang kepribadian diperoleh nilai rata-rata 3,84 dengankriteria jawaban baik. kemudian nilai rata-rata kepribadian tertinggi 4,11 dengan kriteria jawaban baik untuk dimensi keramah-tamahan pada indikator saling memaafkan. Sedangkan nilai ratarata terendah 3,25 dengan kriteria jawaban cukup baik untuk dimensi kehati-hatian pada indikator tanggung jawab dalam menyelesaikan pekerjaannya.

b. Hasil analisis deskriptif kualitatif tentang motivasi diperoleh nilai rata-rata 3,82 dengan kriteria jawaban baik. Kemudian nilai rata-rata tertinggi 4,20 dengan kriteria jawaban baik untuk dimensi kebutuhan akan afiliasi pada indikator hubungan dengan rekan kerja. sedangkan nilai rata-rata terendah 3,22 dengan kriteria jawaban cukup baik untuk dimensi kebutuhan akan prestasi dengan indikator semangat dalam mencapai prestasi kerja.

c. Hasil analisis deskriptif kuantitatif tentang kinerja pegawai diperoleh nilai rata-rata 3,85 dengan kriteria jawaban baik. Kemudia nilai rata-rata tertinggi 4,15 dengan kriteria jawaban baik untuk dimensi perilaku kerja pada indikator kemampuan dalam memimpin tim kerja. sedangkan nilai rata-rata terendah 3,20 dengan kriteria jawaban cukup baik untuk dimensi sasaran kerja pegawai pada indikator waktu dalam menyelesaikan pekerjaan.

d. Hasil analisis regresi linier berganda menunjukkan adanya pengaruh yang positif antara kepribadian $\left(\mathrm{X}_{1}\right)$ dan motivasi $\left(\mathrm{X}_{2}\right)$ terhadap kinerja pegawai (Y) pada Kantor Kementerian Agama Kota Pematangsiantar.

e. Hasil analisis koefisien korelasi menunjukkan adanya hubungan yang kuat dan positif antara kepribadian, motivasi dengan kinerja pegawaipada Kantor Kementerian Agama Kota Pematangsiantar. Kemudian nilai koefisien determinasi menunjukkan baik tidaknya kinerja pegawai (Y) pada 
Kantor Kementerian Agama Kota Pematangsiantar dapat dijelaskan oleh kepribadian $\left(\mathrm{X}_{1}\right)$ dan motivasi $\left(\mathrm{X}_{2}\right)$.

f. Hasil pengujian hipotesis secara simultan dengan uji $\mathrm{F} \mathrm{H}_{0}$ ditolak, hal ini menunjukkan bahwa adanya pengaruh yang positif dan signifikan antara variabel kepribadian dan motivasi terhadap kinerja pegawai pada Kantor Kementerian Agama Kota Pematangsiantar.

g. Hasil pengujian hipotesis secara parsial dengan uji $\mathrm{t} \mathrm{H}_{0}$ ditolak, hal ini menunjukkan bahwa adanya pengaruh yang positif dan signifikan antara variabel kepribadian dan motivasi terhadap kinerja pegawai pada Kantor Kementerian Agama Kota Pematangsiantar.

\section{Saran}

a. Untuk meningkatkan kepribadian pada Kantor Kementerian Agama Kota Pematangsiantar perlu ditingkatkan karena masih ada indikator yang belum optimal. Untuk itu pegawai dalam mengerjakan tugas-tugasnya sebaiknya memperhatikan waktu atau hasil dari apa yang dikerjakan, bekerja dengan sepenuh hati dan memiliki kejujuran yang baik dalam bekerja.

b. Untuk meningkatkan motivasi pada Kantor Kementerian Agama Kota Pematangsiantar perlu ditingkatkan karena masih ada indikator yang belum optimal. Untuk itu sebaiknya instansi memberikan bonus atau insentif bagi pegawai yang berprestasi, dan mengadakan liburan tahunan atau bulanan sehingga dapat meningkatkan motivasi dan semangat kerja pegawai.

c. Untuk meningkatkan kinerja pegawai Kantor Kementerian Agama Kota Pematangsiantar, sebaiknya pegawai menyelesaikan tugas yang diberikan sesuai dengan target yang telah ditentukan oleh instansi, lebih memperhatikan jadwal kerja agar dapat menyelesaikan pekerjaan dan mencatat daftar kerjaan untuk esok hari agar lebih mudah dikerjakan.

d. Sehubungan dengan keterbatasan yang ada pada penulis, penelitian ini masih terdapat kelemahan-kelemahan dan belum dapat mengungkap seluruh variabel yang dapat mempengaruhi kinerja pegawai pada Kantor Kementerian Agama Kota Pematangsiantar, sebagian bahan masukan untuk penelitian selanjutnya, perlu memperbanyak variabel seperti komunikasi, budaya organisasi kepuasan kerja dan variabel lainnya yang tidak diteliti dalam penelitian ini.

\section{E. DAFTAR PUSTAKA}

Agus, Sugianto Frana. 2011. Pengaruh

Komitmen Kerja dan

Kepemimpinan Terhadap Kinerja Karyawan Pada PT Madu Baru Yogyakarta: Universitas Pembangunan Nasional. Veteran. Yogyakarta. Skripsi.2018.

Bangun, Wilson. 2012. Manajemen. Edisi Kelima. Jilid 1. Jakarta: Erlangga

Bintoro, M. T dan Daryanto. 2017. Manajemen Penilaian Kinerja

Karyawan. Cetakan Pertama. Yogyakarta: Penerbit Gava Media.

Daft, Richard L. 2008. Manajemen, Edisi Keenam. Jilid 1. Jakarta: Salemba. Empat.

Darsana, I. Made. 2014. The Influence of Personality on Employee Performance through Organization Citizenship Behavior.. Faculty of Economic. University of

Mahasaraswati.

Denpasar.International Journal.

Volume 3. No 4. October. http://www.theijm.com. 2018.

Dewi, Lusyana. 2016. Pengaruh Kepribadian dan Kecerdasan Emosional Terhadap Kinerja Karyawan Pada Studio Tv Lokal Lampung: Universitas Lampung. Skripsi.2018

Edison, Emron, Yohny Anwar, dan Imas Komariyah. 2016. Manajemen Sumber Daya Manusia. Penerbit Alfabeta.

Gaol, Chr. Jimmy L. 2014. Human Capital Manajemen Sumber Daya Manusia: Konsep, Teori, dan Pengembangan dalam Konteks 
Organisasi Publik dan Bisnis. Jakarta: PT Grasindo.

Griffin, Ricky W. 2004. Manajemen. Jilid 1, Edisi Ketujuh. Jakarta: Erlangga.

Ghozali, Imam. 2013. Aplikasi Analisis Multivariate dengan Program IBM SPSS 21 (Update PLS Regresi). Edisi Ketujuh. Badan Penerbit UNDP: Semarang.

Handoko, T. Hani. 2009. Manajemen. Cetakan Duapuluh. Yogyakarta: BPFE.

Indarti Sri, 2014. Pengaruh Faktor Kepribadian Pegawai dan Lingkungan Kerja Terhadap Kinerja Pegawai Pada Kantor Ragional. Universitas Riau. Jurnal Ekonomi. Volume 22. No 1. Maret. http://id.portalgaruda.org.com. 2018.

Isvandiari, Any. 2014. Pengaruh Kepribadian dan Disiplin Kerja Terhadap Kinerja Karyawan Dinas Luar Asuransi Jiwa Bersama Bumi Putera Cabang Dieng Malang: STIE Asia Malang. Skripsi. 2018.

Ivancevich, John M. 2006. Perilaku dan Manajemen Organisasi. Edisi Ketujuh. Penerbit Erlangga.

Kadarisman, M. 2012. Manajemen Pengembangan Sumber Daya Manusia. Edisi Pertama. Jakarta.

Kasmir, Dr. 2016. Manajemen Sumber Daya Manusia. Cetakan Pertama. Jakarta: Penerbit Grafindo Persada.

Kreitner, Robert dan Kinicki Angelo. 2014. Perilaku Organisasi. Edisi Kesembilan. Jakarta: Salemba Empat.

Luthans, F. 2005. Perilaku Organisasi. Edisi Kesepuluh. Yogyakarta: Andi

Mangkunegara, Anwar Prabu. 2009. Manajemen Sumber Daya Manusia. Cetakan Kesembilan.Bandung: PT Remaja Rosdakarya.

Mondy, R Wayne. 2008. Manajemen Sumber Daya Manusia. Edisi Kesepuluh, Jilid 1. Jakarta: Erlangga.

Noerhayati, Endah. 2011. Pengaruh Motivasi dan Komitmen Organisasi Terhadap Kinerja Karyawan Pada CV. Tirta Makmur Ungaran Semarang: Universitas Negeri Semarang. Skripsi. 2018.
Pasal 5 Undang-undang Nomor 17. 1999. Tentang Fungsi Penyelenggaraan Haji.

Pasal 108 Keputusan Menteri Agama Nomor 373. 2002. Tentang Tugas Dan Fungsi Penyelenggaraan Syariah.

Peraturan Pemerintah RI Nomor 46. 2011. Tentang Penilaian Prestasi Kerja Pegawai.

Peraturan Kepala Badan Kepegawaian Negara Nomor 01. 2013. Petunjuk Pelaksanaan Penilaian Prestasi Kerja Pegawai Negeri Sipil.

Priansa, J. Donni, 2014. Perencanaan dan Pengembangan SDM Bandung: Alfabeta.

Rivai, Veithzal. 2009. Manajemen Sumber Daya Manusia. Jakarta: Raja Grafindo Persada.

Robbins, Stephen P. Dan Timothy A. Judge. 2008. Perilaku Organisasi. Edisi Kedua Belas. Jakarta: Salemba Empat.

Sjarkawi. 2008. Membentuk Kepribadian Anak. Jakarta: PT Bumi Aksara.

Simbolon, Hotman. 2009. Statistika. Yogyakarta: Graha Ilmu.

Sutrisno, Edy. 2011. Manajemen Sumber Daya Manusia. Edisi Pertama. Jakarta: Kencana Prenada Media Group.

Sule, Erni Tisnawati Dan Kurniawan Saefullah. 2005. Pengantar Manajemen. Edisi Pertama. Jakarta: Kencana Prenada Media Group.

Sugiyono. 2013. Metode Penelitian Pendekatan Kuantitatif, Kualitatif dan R\&D. Bandung: Alfabeta.

Wibowo. 2016. Perilaku Dalam Organisasi. Cetakan Keempat. Edisi Kedua. Jakarta: Rajawali.

Wirawan. 2014. Kepemimpinan. Cetakan Kedua edisi Pertama. Jakarta: Rajawali Pers. 